\begin{tabular}{l|c|c}
\hline ISSN: 0001-5113 & ACTA ADRIAT., & ORIGINAL SCIENTIFIC PAPER \\
AADRAY & $59(2): 161-172,2018$ & \\
\hline
\end{tabular}

DOI:10.32582/aa.59.2.1.

\title{
Cell cycle alterations in the mussel Mytilus galloprovincialis hemocytes caused by environmental contamination
}

\author{
Iris BATEL, Maja FAFANĐEL, Mirta SMODLAKA TANKOVIĆ, \\ Ivan IVETAC and Nevenka BIHARI* \\ Ruđer Bošković Institute, Center for Marine Research, \\ G. Paliaga 5, 52210 Rovinj, Croatia
}

*Corresponding author, e-mail: bihari@irb.hr

Environmental contamination includes a mixture of organic substances that can have detrimental effects on marine organisms and should be evaluated in the quality and risk assessment of investigated marine areas. Marine areas selected for this study are a protected area, a mariculture area, a shipyard and an industrial area. Based on the toxicity of the organic seawater extracts these areas were classified as an undisturbed reference area (S1), an area with the low anthropogenic impact (S2), a potentially endangered area (S3) and an area with high anthropogenic impact (S4) respectively. The organic mixtures present in seawater samples collected at the above defined areas were tested for the induction of DNA damage and cell cycle alterations in the mussel Mytilus galloprovincialis hemocytes. Flow cytometric analyses were performed to detect changes in hemocytes DNA content distribution throughout the cell cycle. Organic seawater extracts from sampling sites $S 2, S 3$ and $S 4$ induced an increase in the coefficient of variation of the $G_{0} / G_{1}$ peak and an increase in the number of cells in the $G_{2} / M$ phase reflecting the extent of DNA damage and $G_{2} / M$ arrest, respectively. The $G_{2} / M$ arrest in mussel hemocytes was concentration-dependent upon injection with organic seawater extracts from the S3 site and time dependant for S2, S3 and S4 sampling sites. The time dependence of the induction of the $G_{2} / M$ arrest showed a characteristic pattern for each site due to the different quantitative and qualitative composition of the organic seawater extracts. The $G_{2} / M$ arrest was reversible 24 or 72 hours after treatment with organic seawater extracts from S2 or S3, and S4 sites, respectively. This reversibility was time-and site-specific indicating that such DNA damage is repairable to a certain degree according to the organic seawater extract composition. Thus, the hemocytes cell cycle alterations in the mussel Mytilus galloprovincialis caused by organic seawater extracts reliably reflect the extent of organic contamination effects for selected marine areas.

Key words: organic contamination, flow cytometry, DNA damage, $\mathrm{G}_{2} \mathrm{M}$ arrest, hemocytes, Mytilus galloprovincialis 


\section{INTRODUCTION}

Marine pollution monitoring programs have been widely implemented since the 70 -ies in order to evaluate the levels of anthropogenic impact on marine ecosystems with respect to increased urbanization and industrialization along the coastal zones (GOLDBERG et al., 1978). In order to assess the health status of the marine coastal ecosystems, analysis of biota, water and sediment is largely used as well as monitoring of biological effects of different contaminants in marine organisms (LIVINGSTONE, 1993). The mussel Mytilus galloprovincialis is a bioindicator frequently used for monitoring the coastal waters quality (CORSI et al., 2002) and sometimes as a test organism to determine the effect of specific contaminants or environmental mixtures (TEDESCO et al., 2013).

Among a wide range of contaminants, organic pollutants can induce a whole range of deleterious processes in marine organisms. DNA damage, comprising chromosomal aberrations in gills of Mytilus galloprovincialis (ALSABTI \& KURELEC, 1985), sister chromatid exchange in adult and larval Mytilus edulis (DIXON et al., 1985), micronuclei formation in gills of Mytilus galloprovincialis (BRUNETTI et al., 1988) and hemocytes of Mytilus edulis (WRISEBERG et al., 1992), as well as strand breaks in gills of Mytilus edulis (NACCI et al., 1992) and other aquatic animals (LEE \& STEINERT, 2003) were reported as a consequence of exposure to environmental contamination. Organic pollutants including PAHs, $\mathrm{PCB}$, and pesticide showed significant modulation of Pacific oyster (Crassostrea gigas) hemocyte activities (GAGNAIRE et al., 2006). Effects of genotoxins/xenobiotics in invertebrates and vertebrates include also specific cell cycle alterations such as the $G_{1}$ delay, the $G_{2} / M$ arrest, increase in the $\mathrm{S}$ phase, aneuploidy, polyploidy and apoptosis. These alterations were easily quantifiable by flow cytometry in oyster hemocytes (FORD et al., 1994), blood samples from green frog (LOWCOCK et al., 1997), whole blood from fish from Chernobyl-contaminated ponds (DALLAS et al., 1998) and clam hemocytes collected at polluted sites of the Saguenay Fjord,
Canada (DEBENEST et al., 2013). Abnormalities in DNA content distribution and progression in neoplastic disorders have been detected in mussels or softshell clams (ELSTON et al., 1990, MOORE et al., 1991, RENO et al., 1994). Cell cycle alterations via hemocyte DNA content distribution analyses have been reported for mussels collected at sampling sites that were under anthropogenic influence (BIHARI et al., 2002) and in mussels treated in vivo with the herbicide 2,4-dichlorophenoxy acetic acid (MIČIĆ et al., 2004). Induction of internucleosomal DNA fragmentation as a marker of apoptosis, was detected in gill tissues from mussels treated with 3-n-butyltin chloride (MIČIĆ et al., 2001). Thus, mussels can serve as test organisms for the determination of DNA damage and cell cycle alterations caused by different substances and mixtures thereof encountered in the environment. In response to DNA damage cell cycle progression is delayed allowing time for the completion of DNA repair before mitosis (CALONGE \& O'CONNELL, 2008). Moreover, flow cytometric analyses of the DNA content in marine mussels can be used as a pollution indicator in ecosystem survival studies of polluted areas.

Based on the above, the aim of this study was to use the mussel Mytilus galloprovincialis as a test organism for the determination of DNA damage and cell cycle alterations in hemocytes caused by a mixture of organic substances present in seawater collected from differently contaminated marine areas. The DNA damage (increase in the coefficient of variation of the $\mathrm{G}_{0} / \mathrm{G}_{1}$ peak) and the $\mathrm{G}_{2} / \mathrm{M}$ arrest (increase in the number of hemocytes in the $\mathrm{G}_{2} / \mathrm{M}$ phase) were measured by flow cytometry. Moreover, likely events of late-phase apoptosis as well as aneuploidy were simultaneously assessed by the same DNA content distribution-based flow cytometric analysis.

\section{MATERIAL AND METHODS}

\section{Seawater and mussel sampling}

Seawater was collected at 4 sampling sites, S1 - protected area, S2 - mariculture area, S3 


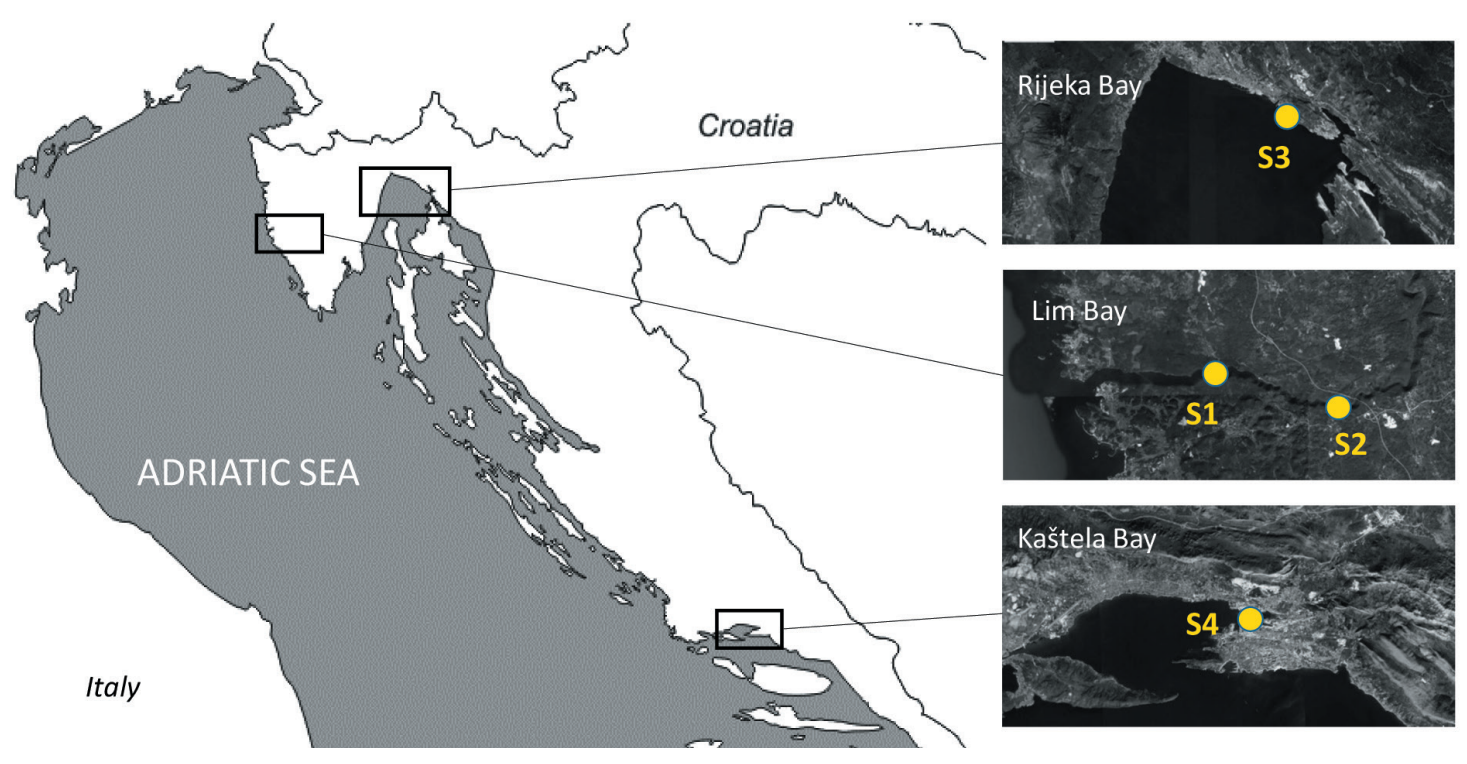

Fig. 1. Map of investigated sampling sites

- ferry port, and S4 - industrial region (Fig. 1). The selected sampling sites are situated at the following areas: Rijeka bay, Lim bay and Kaštela bay. Each site has a different input of organic substances with the main groups of contaminants comprising PAHs (GLAD et al., 2017, MANDIĆ \& PAVELA-VRANČIĆ, 2017), PCBs (HAOP data base, MILUN et al., 2016) and organotins (HAOP data base, ERDELEZ et al., 2017).

Surface seawater $(30 \mathrm{~L})$ was collected in March, June, August and October from 1999 to 2006 at a depth of $0.5 \mathrm{~m}$ using $5 \mathrm{~L}$ containers. The total number of samples was 32 per site.

The mussel Mytilus galloprovincialis (Mollusca: Bivalvia), specimens of 4-5 cm in length, were sampled in a protected area that is not under anthropogenic influence and that serves as a reference site for the Croatian National Monitoring Programs. Mussels were transported in basins with seawater. Specimens were kept in basins at ambient temperature with running seawater for 10 days during the acclimatization period.

\section{Preparation of organic seawater extract}

Organic substances from $30 \mathrm{~L}$ seawater were concentrated by gravity immediately after collection on Amberlite XAD-7 columns (20 mL) at a flow rate of $200 \mathrm{~mL} / \mathrm{min}$. Adsorbed organic substances were eluted with $150 \mathrm{~mL}$ acetone and evaporated to reduce the volume to 30 $\mathrm{mL}$. Purified dichloromethane $(70 \mathrm{~mL})$ that has a high extraction efficiency for a wide range of non-polar to polar compounds was added. The dichloromethane was purified prior to use by distillation, purity checked by gas chromatography and did not show any genotoxic activity (HAMER, 1997). Residual water was removed using anhydrous sodium sulphate. To the clear dichloromethane/acetone mixture 300 $\mu \mathrm{L}$ dimethylsulfoxide (DMSO) was added and evaporated at $38^{\circ} \mathrm{C}$ under vacuum. The remaining $300 \mu \mathrm{L}$ DMSO containing the concentrated organic substances derived from the $30 \mathrm{~L}$ seawater samples was stored at $4^{\circ} \mathrm{C}$ prior to toxicity testing.

\section{Toxicity testing}

The potential toxicity of seawater organic extracts was measured by the bacterial bioluminescence Microtox bioassay (BIHARI et al., 2004, FAFANĐEL \& BIHARI, 2007). The assay measures the decrease of bacterial (Vibrio fisheri) luminescence after exposure to a series of extract dilutions. It was performed using BioFix ${ }^{\circledR}$ Lumi (Macherey-Nagel, Germany) following manu- 
factures instruction, in a Microtox ${ }^{\circledR}$ Model 500 luminometer (AZUR, Environmental, USA). Estimates of $\mathrm{EC}_{50}$ were obtained by the MicrotoxOmni ${ }^{\mathrm{TM}}$ Software package supplied by the manufacturer. To avoid seasonal and punctual events the composite of 32 samples of organic extracts per site (aliquot of $50 \mu \mathrm{L}$ each) was prepared for further analyses.

\section{Treatment of mussels}

Mussels collected in the protected area were used for testing DNA damage and cell cycle alterations in hemolymph caused by concentrated organic substances from four variously contaminated areas. A total of 480 mussels (120 per each contaminated area) were injected directly into the open circulatory system under the mantle with $50 \mu \mathrm{L}$ of $10 \%, 25 \%$ and $100 \%$ concentrated organic substances diluted in DMSO (40 mussels per concentration). The percentages of concentrated organic substances used reflect the equivalent to $0.5 \mathrm{~L}, 1.25 \mathrm{~L}$ and $5 \mathrm{~L}$ of seawater, respectively. Mussels were kept in basins with running seawater at room temperature for $1 \mathrm{~h}$, $24 \mathrm{~h}, 48 \mathrm{~h}$ and $72 \mathrm{~h}$. Ten mussels per location, concentration and time were analysed.

\section{Flow cytometry}

The cell cycle analysis was performed according to BIHARI 2017. Briefly, $100 \mu \mathrm{L}$ of mussel hemolymph was taken from the adductor muscle and stained with $1 \mathrm{~mL}$ of original DAPI staining solution (Partec GmbH, Germany). Stained hemocytes samples were analyzed with a PAS III flow cytometer (Partec, Münster, Germany) at a flow rate of 200-400 cells/s, excitation by $100 \mathrm{~W}$ mercury lamp and emission at $461 \mathrm{~nm}$ for the DAPI signal. From each sample, $2 \times 10^{4}$ hemocytes were analyzed. Measurements were repeated in three separate series. As an instrument calibration, standard trout erythrocytes were used, whereas as an internal fluorescence standard freshly isolated and fixed mussel sperm was used (ELSTON et al., 1988, BIHARI et al., 2003). The results of the flow cytometric analyses include the DNA content distribution profile, the calculation of the $\mathrm{G}_{0} / \mathrm{G}_{1}$ coefficient of variation (CV) and the percentages of cells in each cell cycle phase analyzed by the software package (Partec FloMax Software ${ }^{\circledR}$ ver 2.4e) supplied with the flow cytometer.

\section{Statistics}

For the determination of the statistical significance between groups, the non-parametric Mann-Whitney test was performed with STATISTICA 8.0 (StatSoft, Inc., USA).

\section{RESULTS}

Organic seawater extracts from investigated sites, corresponding to various organic loads, exhibit different toxic potential. Potential toxicities can be measured by the Microtox test revealing five specific classes of seawater quality (BIHARI et. al., 2004). The quality criteria was established based on a 3 years monitoring survey period of Croatian Adriatic waters. Based on the Microtox test five water quality classes have been established: excellent, good, fair, poor and very poor. In Croatian Adriatic waters only three classes of water quality have been shown to exist: excellent, good and fair (BIHARI et. al., 2004). The "fair" water quality represents a fairly polluted, stressed environment with the highest anthropogenic load detected in the Adriatic. The class of "fair" water quality was attributed to samples that express a value of $\mathrm{EC}_{50}<138 \mathrm{ml}$ of seawater in the Microtox test. In this study four sampling sites were categorized based on the above criteria revealing different frequency of "fair" seawater quality (Table 1). The frequencies of "fair" seawater quality were $28 \%, 32 \%$, $45 \%$, and $68 \%$ that correspond to an undisturbed reference area, an area with the lowest anthropogenic impact, a potentially endangered area and an area with high anthropogenic impact respectively.

We hypothesized that seawater extracts containing organic substances from contaminated areas could cause DNA damage and cell cycle alterations in the hemolymph of mussel Mytilus galloprovincialis. Therefore, the flow cytomet- 
Table 1. Frequency of "fair" seawater quality at selected sampling sites

\begin{tabular}{cccc}
$\begin{array}{c}\text { Sampling } \\
\text { site }\end{array}$ & $\begin{array}{c}\text { Number of } \\
\text { samples (n) }\end{array}$ & $\begin{array}{c}\text { Frequency of fair* } \\
\text { seawater quality }(\%)\end{array}$ & Area description \\
\hline S1 & 32 & 28 & Undisturbed reference area \\
S2 & 32 & 32 & Low anthropogenic impact \\
S3 & 32 & 45 & Potentially endangered area \\
S4 & 32 & 68 & High anthropogenic impact \\
\hline
\end{tabular}

* $E C_{50}<136 \mathrm{ml}$ (according to Fafanđel and Bihari, 2007)
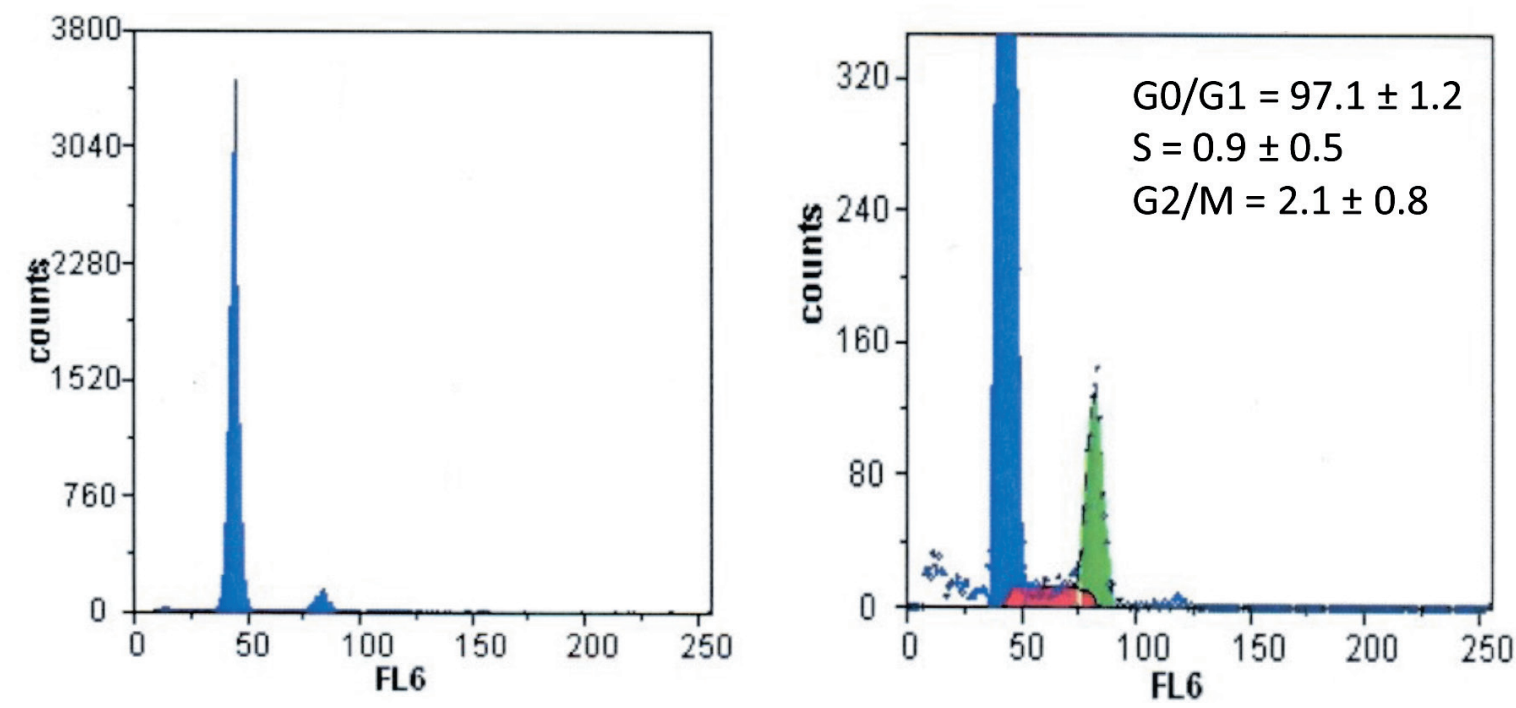

Fig. 2. Hemocyte cell cycle profile of untreated mussels Mytilus galloprovincialis from a protected area $(n=10)$ with cell cycle analyses

Table 2. DNA damage in hemocytes of mussel Mytilus galloprovincialis one hour after treatment

\begin{tabular}{ccc}
$\begin{array}{c}\text { Sampling } \\
\text { site }\end{array}$ & $\begin{array}{c}\text { Number of } \\
\text { samples }(\mathrm{n})\end{array}$ & $\mathrm{CV}$ of $\mathrm{G}_{0} / \mathrm{G}_{1}$ peak \\
\hline control & 10 & $4.4 \pm 0.3$ \\
S1 & 10 & $4.6 \pm 0.3$ \\
S2 & 10 & $6.0 \pm 0.9 *$ \\
S3 & 10 & $5.2 \pm 0.2^{*}$ \\
S4 & 10 & $7.0 \pm 0.9 *$ \\
\hline
\end{tabular}

$* p<0.05$

ric analyses of hemocytes DNA content and cell cycle distribution were performed on mussels injected with organic seawater extracts from different sampling areas. Moreover, the coefficients of variation $(\mathrm{CV})$ of the $\mathrm{G}_{0} / \mathrm{G}_{1}$ peak as a measure of DNA damage were established
(BIHARI, 2017). Typical hemocyte DNA content histograms were obtained for control mussels sampled in the protected area (Fig. 2) with the $\mathrm{G}_{0} / \mathrm{G}_{1}$ peak $\mathrm{CV}<4.5$.

The treatment of mussels with organic seawater extracts from sampling sites S2, S3 and $\mathrm{S} 4$, caused an increase in the $\mathrm{G}_{0} / \mathrm{G}_{1}$ peak $\mathrm{CV}$, indicative of the induced DNA damage in mussel hemocytes (Table 2). The highest DNA damage induction was observed in hemocytes of mussels injected with organic seawater extracts from the S4 sampling site (an area of high anthropogenic impact).

Flow cytometric analyses of DNA content also revealed the proportion of cells in $G_{0} / G_{1}, S$ and $\mathrm{G}_{2} / \mathrm{M}$ phases during the cell cycle of mussel M. galloprovincialis hemocytes (Table 3). Treatment with organic seawater extracts from 
Table 3. Proportion of cells in G0/G1, S and G2/M phases in the cell cycle of mussel Mytilus galloprovincialis hemocytes one hour after treatment.

\begin{tabular}{ccccc}
$\begin{array}{c}\text { Sampling } \\
\text { site }\end{array}$ & $\begin{array}{c}\text { Number of } \\
\text { samples }(\mathrm{n})\end{array}$ & $\begin{array}{c}\mathrm{G}_{0} / \mathrm{G}_{1} \text { phase } \\
(\%)\end{array}$ & $\begin{array}{c}\mathrm{S} \text { phase } \\
(\%)\end{array}$ & $\begin{array}{c}\mathrm{G}_{2} / \mathrm{M} \text { phase } \\
(\%)\end{array}$ \\
\hline control & 10 & $97.1 \pm 1.2$ & $0.9 \pm 0.5$ & $2.1 \pm 0.8$ \\
S1 & 10 & $96.9 \pm 1.3$ & $0.9 \pm 0.7$ & $2.2 \pm 0.8$ \\
S2 & 10 & $93.0 \pm 2.2^{*}$ & $1.5 \pm 0.6$ & $5.5 \pm 1.9^{*}$ \\
S3 & 10 & $93.6 \pm 1.6^{*}$ & $1.4 \pm 1.1$ & $5.0 \pm 1.1^{*}$ \\
S4 & 10 & $91.1 \pm 2.4^{*}$ & $1.4 \pm 1.0$ & $7.6 \pm 2.3^{*}$ \\
\hline
\end{tabular}

$* p<0.05$

sampling sites $\mathrm{S} 2, \mathrm{~S} 3$ and $\mathrm{S} 4$ showed a decrease in the percentage of hemocytes in the $\mathrm{G}_{0} / \mathrm{G}_{1}$ phase. The proportion of S-phase hemocytes was not altered, while the proportion of $\mathrm{G}_{2} / \mathrm{M}$ phase hemocytes increased. Such cell cycle distribution in mussel hemocytes is indicative of a $\mathrm{G}_{2} / \mathrm{M}$ arrest. Treatment with organic seawater extracts after $1 \mathrm{~h}$ lead to the maximal $\mathrm{G}_{2} / \mathrm{M}$ arrest of $5.5 \%, 5.0 \%$ and $7.6 \%$ for sampling sites S2, S3 and S4 respectively, in comparison with the control (2.1\%). No concurrent apoptotic changes were observed.

The relationship between DNA damage, expressed as an increase in the $\mathrm{G}_{0} / \mathrm{G}_{1}$ peak $\mathrm{CV}$,

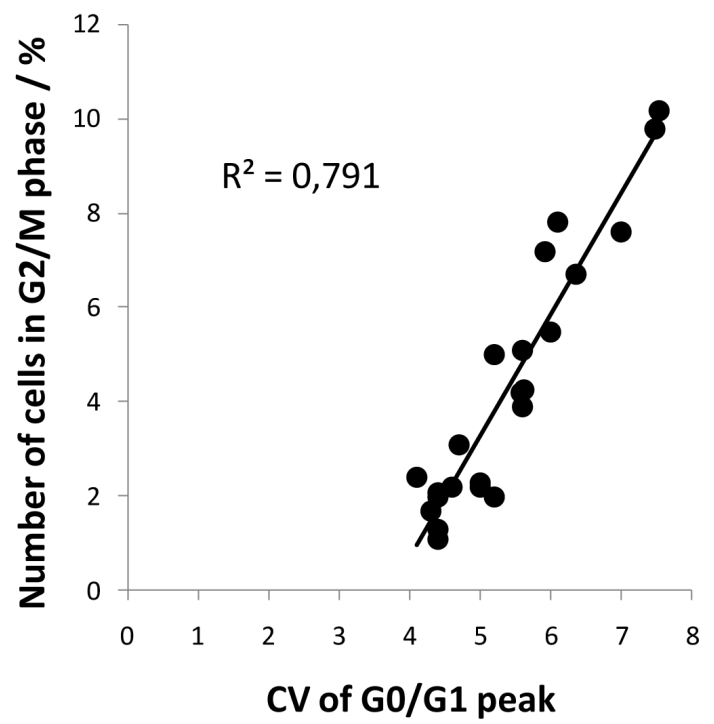

Fig. 3. Correlation between DNA damage and number of cells in $G_{2} / M$ phase $\left(G_{2} / M\right.$ arrest) in hemocytes of mussels one hour after injection with organic seawater extracts. and $\mathrm{G}_{2} / \mathrm{M}$ arrest, expressed as an increase in hemocyte content in the $\mathrm{G}_{2} / \mathrm{M}$ phase, was examined next (Fig. 3). An increase in DNA damage in mussel hemocytes one hour after injection with organic extracts from differentially contaminated areas followed the accumulation of cells in $G_{2} / M$ phase (increase in $G_{2} / M$ arrest).

The $G_{2} / M$ arrest in hemocytes of mussels injected with the organic seawater extract from S3 was concentration-dependent after $24 \mathrm{~h}$ of recovery (Fig. 4). Mussels injected with organic seawater extracts from the remaining sampling sites did not show any concentration-dependent response with respect to $G_{2} / M$ arrest (data not shown).

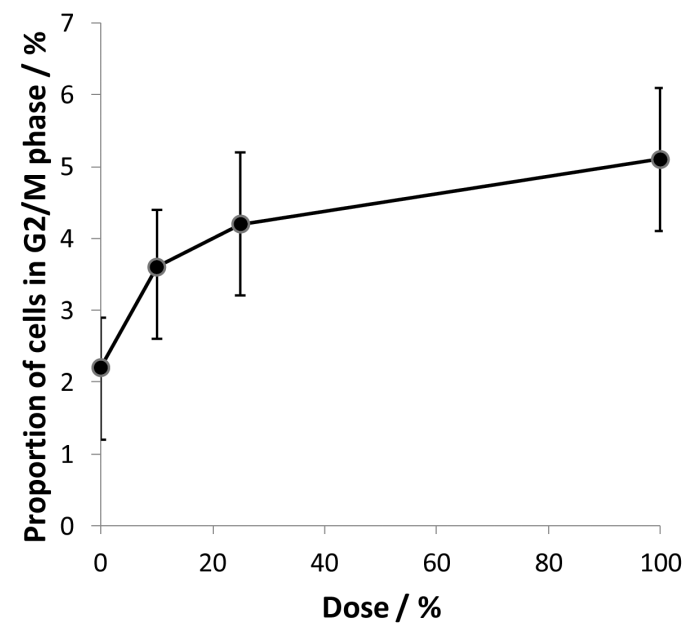

Fig. 4. Number of cells in $G_{2} / M$ phase calculated from hemocytes single-parameter histograms of mussel injected with different organic seawater concentrations from the $S 3$ area. Each point represents a mean value with standard deviation of five independent mussels analyzed 24 hours after injection. 


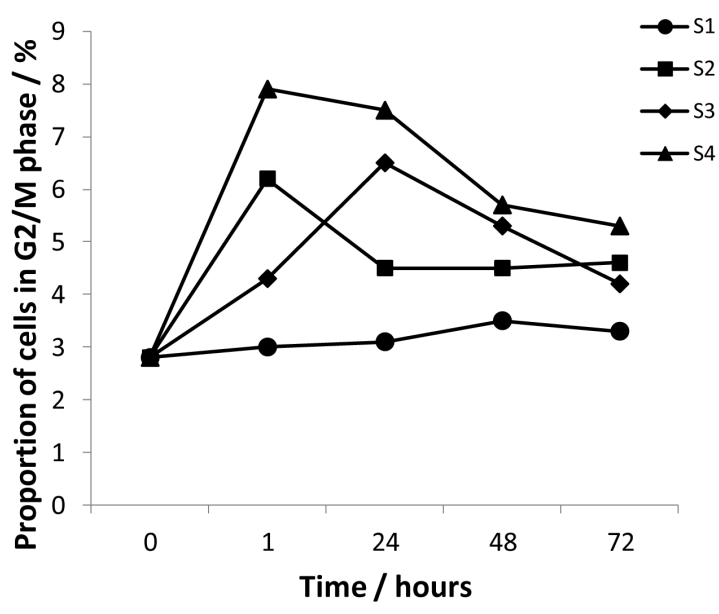

Fig. 5. Number of cells in the $G_{2} / M$ phase calculated from hemocytes single-parameter histograms of mussel injected with organic seawater extracts from different areas (S1, S2, S3 and S4) and analyzed at different times after injection. Each point represents a mean value of five mussels.

Furthermore, DNA flow cytometric analyses indicated that the recovery of $\mathrm{G}_{2} / \mathrm{M}$ arrests in hemocytes was time-dependent after injection of mussels with organic seawater extracts from S2, S3 and S4 (Fig. 5). An accumulation of mussel hemocytes at $\mathrm{G}_{2} / \mathrm{M}$ arrest was observed within the first hour of injection with organic seawater extracts from sites $S 2, S 3$ and $S 4$. The $G_{2} / M$ arrest reached its maximum within one hour of injection with the organic seawater extract from $\mathrm{S} 2$. It increased during $24 \mathrm{~h}$ reaching its maximum in hemocytes of mussels injected with the organic extract from S3. The highest extent of the $\mathrm{G}_{2} / \mathrm{M}$ arrest, which lasted for $24 \mathrm{~h}$, was induced with the organic seawater extract from S4. The incidence of $\mathrm{G}_{2} / \mathrm{M}$ arrests were partially reversible $24 \mathrm{~h}$ after injection with the organic seawater extracts from $\mathrm{S} 2$ and $72 \mathrm{~h}$ after injection with those from S3 and S4.

\section{DISCUSSION}

At present, the analysis of biota for monitoring purposes is a widely accepted concept. It has been included in the EU Marine Strategy Framework Directive (2010) as the approach for the assessment of marine seawater quality in order to achieve good environmental status. The most common approach is the assessment of biological alterations in the mussels Mytilus galloprovincialis which have been widely established to reliably reflect qualities of the environment at the investigated sites. Though these data are of great value, there is a lack of specific evidence concerning the precise identities of contaminant mixtures that bring about such alterations. While chemical analyses of seawater collected at investigated sites are certainly helpful, they are not sufficient since they reveal a wide range of specific substances of both organic and inorganic origin. In the actual marine environments, pollutants typically occur in mixtures (MOORE, 2002) and the toxic effects of such mixtures tend to be exerted cumulatively, exceeding the individual toxicity of any single component (FAUST et al., 2001). However, the majority of reported toxicity data is related to single substances, not to mixtures. We investigated the biological effect of organic mixtures present in seawater collected at different sampling sites on mussel hemocytes. The organic seawater extracts used contain a mixture of organic compounds that differ both in quality and quantity depending on the sampling site (HAOP data base). These organic extracts represent a composite of an 8 years seawater sampling period. Based on toxicity analyses of organic seawater extracts, sampling sites were characterized as an undisturbed reference area (S1), an area with the low anthropogenic impact (S2), a potentially endangered area (S3) and an area with high anthropogenic impact (S4). These sites correspond to a protected area, a mariculture area, a shipyard and an industrial area, respectively.

Upon an organism's exposure to environmental genotoxic agents, such as certain organic substances (e.g. PAHs), DNA damage is a common initial event (FULDA et al., 2010). Previous studies have revealed that hemocytes from clams collected at polluted sites showed an increased DNA content variation (increases in $\mathrm{CV}$ of $\mathrm{G}_{0} /$ $G_{1}$ peak in flow cytometric analyses of hemocyte DNA content distribution), reduced DNA strand breaks repair activity and an increased frequency of the occurrence of micronuclei (DEBENEST et al., 2013). The results of the pre- 
sent study revealed induction of DNA damage in hemocytes of mussels $M$. galloprovincialis injected with seawater extracts from S2, S3 and $\mathrm{S} 4$. The DNA damage was measured as an increase in $C V$ of the $G_{0} / G_{1}$ peak. The largest increase in $C V$ of the $G_{0} / G_{1}$ peak was detected in mussels injected with organic extracts from $\mathrm{S} 4(\mathrm{CV}>7)$. A CV larger then in control samples often results from chromosomal aberrations caused by clastogenic agents - mutagens inducing disruption or breakages of chromosomes (GALLOWAY, 1994) and may also be due to the partial inclusion of an aneuploidy peak within the diploid $\mathrm{G}_{0} / \mathrm{G}_{1}$ peak (SUN, 1993). Moreover, DNA profiles comprising normal DNA content patterns with additional aneuploidy peaks were detected in native mussels collected at S4 (BIHARI et al., 2003). It is hence very plausible that the organic extract from S4 contains substances whose genotoxic activity may individually or collectively result in aneuploidy events.

DNA content profiling by flow cytometry also allows detection of apoptosis. Cell cycle alterations characteristic for apoptotic process in mussels have been reported for certain sites in the Adriatic (BIHARI et al., 2003). However, no pattern changes in DNA content characteristic of the onset of apoptosis were observed for mussels treated with organic extracts from seawater collected at any of the sampling sites.

Flow cytometric analyses of the DNA content revealed differences in the number of hemocytes in the $G_{2} / M$ phase $\left(G_{2} / M\right.$ arrest $)$ of mussels treated with seawater extracts from S2, S3 and S4. Such differences in the capacity for induction of the $G_{2} / M$ arrest are ascribed to the likely variation in the qualitative and quantitative composition of organic substances present at the areas represented by organic seawater extracts. It is common understanding that the $\mathrm{G}_{2} / \mathrm{M}$ checkpoint of the cell cycle prevents cells from initiating mitosis when they experience DNA damage, while under the latter circumstances, the ensuing $\mathrm{G}_{2} / \mathrm{M}$ arrest serves to provide more time for DNA repair. The concurrently observed increases in $\mathrm{CV}$ of the $\mathrm{G}_{0} /$ $G_{1}$ peak and the greater proportion of cells in the $\mathrm{G}_{2} / \mathrm{M}$ phase indicated a quantitative corre- lation between DNA damage and $\mathrm{G}_{2} / \mathrm{M}$ arrest. An increase in DNA damage resulted in cell accumulation in the $G_{2} / M$ phase. In addition, the occurrence of $\mathrm{G}_{2} / \mathrm{M}$ arrest in the absence of apoptosis is strongly suggestive of single-strand DNA breaks (FULDA et al., 2010). Thus, single strand breaks are probably the predominant type of DNA damage in hemocytes of mussels treated with organic seawater extracts from S2 and S3 sites. However, additional confirmation of the specific type of DNA damage is necessary.

The increased proportion of hemocytes in the $G_{2} / M$ phase $\left(G_{2} / M\right.$ arrest $)$ caused by organic extracts from S3 was concentration-dependent. However, such concentration-dependence was not observed for organic extracts from S2 and S4 sites (for the 10\% - 100\% experimental concentration range). The treatment with $10 \%$ organic extract from S2 and S4 sites was sufficient to produce a high extent of DNA damage $(\mathrm{CV}>6)$ and correspondingly a high occurrence of $\mathrm{G}_{2} / \mathrm{M}$ arrest. It is very likely that the organic extracts from the S2 and S4 sites contained very high quantities and/or complex mixtures of harmful substances. Thus, a clear concentrationdependent response curve could not be achieved. The results indicate that an equilibrium between DNA damage and repair took place allowing mussels to cope with further increase in pollutant concentrations $(>10 \%)$ without the expression of additional DNA damage.

The $\mathrm{G}_{2} / \mathrm{M}$ arrest in hemocytes of mussels treated with the organic seawater extracts had a characteristic time pattern for each site. A reason could be the quantitative and qualitative composition of organic mixtures present in extracts causing different amounts of DNA damage that need different times to be repaired. Another reason could be a different repair efficiency of the DNA damage caused by the substances present in the organic seawater extracts. The $\mathrm{G}_{2} / \mathrm{M}$ arrest was reversible, although not completely, 24 or 72 hours after treatment with organic seawater extracts from S2 or S3, S4, respectively. A reversible $G_{2} / M$ arrest was also observed 48 $\mathrm{h}$ after apigenin treatment in the SW480 cell line (WANG et al., 2000). Thus, the $\mathrm{G}_{2} / \mathrm{M}$ arrest decreases when the majority of DNA damage is 
repaired, and the rate of DNA repair depends on the DNA damage/repair equilibrium specific for each organic contaminant mixture.

Concentrated organic substances from 4 variously contaminated areas contained genotoxins that induced DNA damage/cell cycle alterations in mussel hemocytes. The seawater composite extracts from an 8 years' period survey reflected the cumulative pollution incidence at the examined sites. Furthermore, the implemented experimental design could allow the prediction of organic pollution effects on mussels at a long time scale. The observed DNA damage/cell-cycle alterations in hemocytes reliably reflected the extent of the organic contamination at investigated marine areas. DNA damage was repairable to a certain degree. When DNA repair was not successful, DNA damage and cell cycle alterations could have led to gamete loss due to cell death, embryo mortality and abnormal development (DEPLEDGE, 1998). Ultimately, mussels could be used as test organisms to determine the open sea genotoxicity loads, where these organisms do not live.

\section{CONCLUSIONS}

For marine quality and risk assessment, it is important to determine biological effects in marine organisms caused by organic fractions derived from the actual marine environmental contamination. Organic extracts from differentially contaminated areas contain a mixture of substances that differ in their qualitative and quantitative composition.
Consequently, the observed effects of organic seawater extracts on hemocytes cell-cycle dynamics in the mussel Mytilus galloprovincialis were site-specific. While the organic extract from the undisturbed area (S1) did not alter cell-cycle dynamics in mussels' hemocytes, the organic extracts from the other sites induced different types and extent of DNA damage. The predominant type of DNA damage observed were probably single-stranded breaks caused by organic extracts from sites of low anthropogenic impact (S2) and potentially endangered area (S3). Organic extracts from the site of high anthropogenic impact (S4) most likely induce aneuploidy. Organic seawater extracts from three sites (S2, S3 and S4) inhibit hemocyte division by inducing $G_{2} / M$ arrest. An increased percentage of cells in $G_{2} / M$ phase occur as a consequence of the increase in DNA damage. The overcoming of $\mathrm{G}_{2} / \mathrm{M}$ arrest in mussel hemocytes was time-dependent and site-specific, revealing that DNA damage is repairable to a certain degree depending on the organic seawater extract composition. Thus, cell-cycle alterations in hemocytes reliably reflect the extent of organic contamination at investigated marine areas.

\section{ACKNOWLEDGEMENTS}

The Croatian Ministry of Science, Education and Sport financially supported this work (Project: 0982705-2725, Ecotoxic effects of contamination on marine organisms, N. Bihari).

\section{REFERENCES}

ALSABTI, K. \& B. KURELEC. 1985. Induction of chromosomal aberrations in the mussel Mytilus galloprovincialis watch. Bull. Environ. Contam. Toxicol., 35: 660-665.

BIHARI, N., B. HAMER, Ž. JAKŠIĆ, M. FAFANĐEL, M. MIČIĆ, \& R. BATEL. 2002. Application of alkaline elution, fast micromethod and flow cytometry in detection of marine contamination. Cell. Mol. Biol., 48: 373-377.
BIHARI, N., M. MIČIĆ, R. BATEL \& R.K. ZAHN. 2003. Flow cytometric detection of DNA cell cycle alterations in hemocytes of mussels (Mytilus galloprovincialis) off the Adriatic Coast, Croatia. Aquatic Toxicol., 64: 121-129.

BIHARI, N., M. MIČIĆ \& M. FAFANĐEL. 2004. Seawater quality along the Adriatic Coast, Croatia, based on toxicity data. Environ. Toxicol., 19: 109-114. 
BIHARI, N. 2017. Rapid assessment of genotoxicity by flow cytometric detection of cell cycle alterations in Fast Detection of DNA Damage, Methods and Protocols, in Didenko V.V. (Ed.), Methods in Molecular Biology 1644, Humana Press, New York, pp. 13-21.

BRUNETTI, R., F. MAJONE, I. GOLA \& C. BELTRAME. 1988. The micronucleus test: examples of application to marine ecology. Mar. Ecol. Progr. Ser., 44: 65-68.

CALONGE, T.M. \& M.J. O'CONNELL. 2008. Turning off the G2 DNA damage checkpoint. DNA repair (Amst), 7: 136-140

CHOU, G.L., S.F. PENG, C.L. LIAO, H.C. HO, K.W. LU, J.C. LIEN, M.J. FAN, K.C. LA \& J.G. CHUNG 2018 Casticin impairs cell growth and induces cell apoptosis via cell cycle arrest in human oral cancer SCC-4 cells., 33: 127-141.

CORSI, I., M. MARIOTTINI, V. MENCJI, C. SENSINI, C., BALOCCHI \& S. FOCARDI. 2002. Monitoring of marine coastal area: Use of Mytilus galloprovincialis and Mullus barbatus as bioindicators. Mar. Ecol., 23: 138-153.

DALLAS, C.E., S.F. LINGENFELSER, J.T. LINGENFELSER, K. HOLLMAN, C.H. JAGOE, J.A. KIND, R.K. CHESSER \& M.H. SMITH. 1998. Flow cytometric analyses of erythrocyte and leukocyte DNA in fish from Chernobyl-contaminated ponds in the Ukraine. Ecotoxicology, 7: 211-219.

DEBENEST, T., F. GAGNE, T. BURGEOT, C. BLAISE \& J. PELLERIN. 2013. DNA integrity assessment in hemocytes of soft-shell clams (Mya arenaria) in the Saguenay Fjord (Quebec, Canada). Environ. Sci. Poll. Res., 20: 621-629.

DEPLEDGE, M.H. 1998. The ecotoxicological significance of genotoxicity in marine invertebrates. Mutat. Res., 399: 109-122.

DIXON, D.R., I.M. JONES \& F.L. HARRISON. 1985. Cytogenic evidence of inducible processes linked with metabolism of a xenobiotic chemical in adult and larval Mytilus edulis. Sci. Total Environ., 46: 1-8.

ELSTON, R.A., M.L. KENT \& A.S. DRUM. 1988. Progression, lethality and remission of haemic neoplasia in the bay mussel Mytilus edulis. Dis. Aquat. Organ., 4: 135-142.

ELSTON, R.A., A.S. DRUM \& S.K. ALLEN. 1990. Progressive development of circulating poly- ploid cells in Mytilus with hemic neoplasia. Dis. Aquat. Org., 8: 51-59.

ERDELEZ, A., M. FURDEK TURK, A. ŠTAMBUK, I. ŽUPAN \& M. PEHARDA. 2017. Ecological quality status of the Adriatic coastal waters evaluated by the organotin pollution biomonitoring. Poll. Bull., 123: 313-323

FAFANĐEL, M. \& N. BIHARI. 2007. Temporal and spatial variations of seawater toxicity along the Adriatic Coast, Croatia: a long term study. Fresenius Environ. Bull., 16: 14571463.

FAUST, M., R. ALTENBURGER, T. BACKHAUS, H. BLANCK, W. BOEDEKER, P. GRAMATICA, V. HAMER, M. SCHOLZE, M. VIGHI \& L.H. GRIMME. 2001. Predicting the joint algal toxicity of multi-component s-triazine mixtures at loweffect concentrations of individual toxicants. Aquatic Toxicol., 56: 13-32.

FORD, S.E., K. ASHTON-ALCOX \& S.A. KANALEY. 1994. Comparative cytometric and microscopic analyses of oyster hemocytes. J. Invertebr. Pathol., 64: 114-122.

FULDA, S., A.M. GORMAN, O. HORI \& A. SAMALI. 2010. Cellular stress responses: cell survival and cell death. A review. Int. J. Cell Biol., 2010:214074, 23 p.

GAGNAIRE B, H. THOMAS-GUYON, T.H. BURGEOT \& T. RENAULT. 2006. Pollutant effects on Pacific oyster, Crassostrea gigas (Thunberg), hemocytes: screening of 23 molecules using flow cytometry. Cell Biol. Toxicol., 22: 1-14 GALLOWAY, S.M. 1994. Chromosome aberrations induced in vitro: mechanisms, delayed expression and intriguing questions. Environ. Mol. Mutagen., 23 (Suppl. 24): 44-53.

GLAD, M., N. BIHARI, Ž. JAKŠIĆ \& M. FAFANĐEL. 2017. Comparison between resident and caged mussels: Polycyclic aromatic hydrocarbon accumulation and biological response. Mar. Environ. Res., 129: 195-206.

GOLDBERG, E.D., V.T. BOWEN, J.W. FARRINGTON, G. HARVEY, J.H. MARTIN, P.L. PARKER, R.W. RISEBOROUGH, W. ROBERTSON, E. SCHNEIDER \& E. GAMBIE. 1978. The Mussel Watch, Environ. Cons., 5: 101-125.

HAMER, B. 1997. Primjena bakterijskog SOS/ umu-testa u procjeni genotoksičnog djelo- 
vanja smjesa zagađivala i modelnih spojeva. Magistarski rad, Sveučilište u Zagrebu, p. 74. HAOP DATA BASE. State of marine environment, aquaculture and fisheries. Indicators data base. http://www.jadran.izor.hr/azo, Accessed on March 15, 2017.

LEE, R.F. \& S. STEINERT. 2003. Use of the single cell gel electrophoresis/comet assay for detecting DNA damage in aquatic (marine and freshwater) animals. Mutat. Res. 544: 43-64.

LIVINGSTONE, D.R., 1993. Biotechnology and pollution monitoring: Use of molecular biomarkers in the aquatic environment. J. Chem. Technol. Biotechnol., 57: 195-211.

LOWCOCK, L.A., T.F. SHARBEL, J. BONIN, M. OUELLET, J. RODRIGUE \& J.L. DESGRANGES. 1997. Flow cytometric assay for in vivo genotoxic effects of pesticides in green frogs (Rana clamitans). Aquat. Toxicol., 38: 241-255.

MANDIĆ, J. \& M. PAVELA-VRANČIĆ. 2017. Concentrations and origin of polycyclic aromatic hydrocarbons in sediments of the Middle Adriatic Sea. Acta Adriat., 58 (1): 3-24.

MIČIĆ, M., N. BIHARI, Ž. LABURA, W.E.G. MÜLER $\&$ R. BATEL. 2001. Induction of apoptosis in the blue mussel Mytilus galloprovincialis by 3-n-buthyltinchloryde. Aquatic Toxicol., 55: 61-73.

MIČIĆ, M., N. BIHARI \& I. MLINARIČ-RAŠČAN. 2004. Influence of herbicide, 2,4-dychlorophenoxy acetic acid, on hemocyte DNA of in vivo treated mussels. J. Exp. Mar. Biol. Ecol., 311: 157-169.

MILUN, V., D. GRGAS \& T. LANDEKA DRAGIČEVIĆ. 2016. Assessment of PCB and chlorinated pes- ticide accumulation in mussels at Kaštela Bay (Eastern Adriatic). Sci. Tot. Environ., 562, 115-127

MOORE, J.D., R.A. ELSTON, S. DRUM \& M.T. WILKINSON. 1991. Alternate pathogenesis of systematic neoplasia in the bivalve mollusk Mytilus. J. Invertebr. Pathol., 58: 233-243.

MOORE, M.N. 2002. Biocomplexity: the postgenome challenge in ecotoxicology. Aquatic Toxicol., 59: 1-15.

NACCI, D., S. NELSON, V. NELSON \& E. JACKIM. 1992. Application of the DNA alkaline unwinding assay to detect DNA strand breaks in marine bivalves. Mar. Environ. Res., 33: 83-100.

RENO, P.W., M. HOUSE \& A. ILLINWORTH. 1994. Flow cytometric and chromosome analyses of softshell clams Mya arenaria, with disseminated neoplasia. J. Invertebr. Pathol., 64: 163-172.

SUN, T. 1993. Color atlas - text of flow cytometric analysis of hematologic neoplasms. Igaku Shoin, New York, Tokyo, p. 276.

TEDESCO, S., H. DOYLE, D. IACOPINO, D. O'DONOVAN, S. KEANE, \& D. SHEEHAN. 2013. Gold nanoparticles and oxidative stress in blue mussel Mytilus edulis. Methods Mol. Biol., 1028: 197-203.

WANG, W., I. HEIDEMAN, C.S. CHUNG, J.C. PELLING, K.J. KOEHLER, K.J. \&D.F. BIRT. 2000. Cell cycle arrest at $\mathrm{G} 2 / \mathrm{M}$ and growth inhibition by apigenin in human colon carcinoma cell lines. Mol. Carcinog., 26: 102-110.

WRISEBERG, M.N., C.M. BILBO, \& H. SPLIID. 1992. Induction of micronuclei in hemocytes of Mytilus edulis and statistical analyses. Ecotoxicol. Environ. Safety, 23: 191-205.

Received: 4 June 2018

Accepted: 25 September 2018 


\title{
Utjecaj onečišćenja okoliša na promjene u staničnom ciklusu hemocita dagnje Mytilus galloprovincialis
}

\author{
Iris BATEL, Maja FAFANĐEL, Mirta SMODLAKA TANKOVIĆ, \\ Ivan IVETAC i Nevenka BIHARI* \\ *Kontakte-pošta: bihari@irb.hr
}

\begin{abstract}
SAŽETAK
Onečišćenje okoliša čini mješavina organskih tvari s mogućim učincima na morske organizme koje je potrebno procijeniti u sklopu istraživanja vezanih za utvrđivanje kvalitete okolišnog rizika za određeno morsko područje.

Morska područja odabrana za svrhu ove studije uključuju zaštićeno morsko područje, područje marikulture, brodogradilište i industrijsko područje. Na temelju profila toksičnosti organskih ekstrakata uzoraka morske vode, navedena su područja razvrstana na nedirnuto morsko područje (S1), područje niskog antropogenog utjecaja (S2), potencijalno ugroženo područje (S3), odnosno područje visokog antropogenog utjecaja (S4).

Mješavine organskih tvari prisutne $\mathrm{u}$ uzorcima morske vode prikupljenim na utvrđenim područjima testirane su na sposobnost indukcije oštećenja DNA te učinak na stanični ciklus hemocita dagnje Mytilus galloprovincialis. Kako bi se utvrdile promjene u distribuciji sadržaja DNA tijekom staničnog ciklusa hemocite su analizirane protočnom citometrijom. Organski ekstrakti morske vode sa S2, S3 i S4 inducirali su povećanje koeficijenta varijacije $\mathrm{G}_{0} / \mathrm{G}_{1}$ maksimuma kao i porast u broju stanica u $\mathrm{G}_{2} / \mathrm{M}$ fazi, odražavajući zaustavljanje ciklusa tj. " $\mathrm{G}_{2} / \mathrm{M}$ arrest" uslijed oštećenja DNA. Povećanje u količini oštećenja DNA bilo je popraćeno porastom broja hemocita $u$ $\mathrm{G}_{2} / \mathrm{M}$ fazi. Zaustavljanje staničnog ciklusa $\mathrm{u}_{2} / \mathrm{M}$ fazi u hemocitima dagnje pokazalo se ovisnim o primijenjenoj dozi organskog ekstrakta morske vode sa mjesta uzorkovanja S3, a ovisnim o vremenu djelovanja ekstakta morske vode sa mjesta S2, S3 i S4. Utvrđena ovisnost o trajanju induciranog zaustavljanje ciklusa $\mathrm{u}_{2} / \mathrm{M}$ fazi pokazala se karakterističnom za pojedina mjesta uzorkovanja što je posljedica različitih kvantitativnih i kvalitativnih karakteristika samog sastava pojedinih organskih ekstrakata morske vode. Ponovno uspostavljanje zaustavljenog ciklusa u $\mathrm{G}_{2} / \mathrm{M}$ fazi utvrđen je 24 sata nakon primjene organskih ekstrakata morske vode s mjesta $\mathrm{S} 2$, odnosno 72 sata nakon primjene organskih ekstrakata morske sa mjesta S3 i S4.

Ustanovljen oporavak staničnog ciklusa nakon zaustavljanja pokazao se specifično vezanim uz vrijeme djelovanja i mjesto uzorkovanja, što upućuje na to da je popravak oštećenja DNA moguć do određene razine, ovisno o samome sastavu pojedinih organskih ekstrakata morske vode. Stoga se zaključuje da promjene u staničnom ciklusu hemocita dagnje Mytilus galloprovincialis uzrokovane djelovanjem pojedinih organskih ekstrakata vjerno odražavaju razinu štetnog djelovanja organskih zagađivala u odabranim morskim područjima.
\end{abstract}

Ključne riječi: organsko onečišćenje, protočna citometrija, DNA oštećenja, zaustavljanje ciklusa u $\mathrm{G}_{2} / \mathrm{M}$ fazi, hemociti, Mytilus galloprovincialis 